\title{
Spectrum of EGFR gene mutations and ALK rearrangements in lung cancer patients in Turkey
}

\author{
Sebnem Ozemri Sag ${ }^{1}$, Ozlem Gorukmez², Mehmet Ture', Orhan Gorukmez², Adem Deligonul ${ }^{3}$, \\ Serdar Sahinturk' , Ali Topak', Tuna Gulten', Ender Kurt ${ }^{3}$ and Tahsin Yakut ${ }^{* *}$
}

\begin{abstract}
The EGFR gene and ALK rearrangements are two genetic drivers of non-small cell lung cancer (NSCLC). The frequency of EGFR mutations and ALK rearrangement varies according to not only ethnicity but also gender, smoking status and the histological type of NSCLC. In the present study, we demonstrated the distribution of EGFR mutations in 132 NSCLC patients by using a pyrosequencing technique and the distribution of ALK rearrangements in 51 NSCLC patients by using fluorescent in situ hybridization technique in Turkey. Additionally, we compared the clinicopathological data of NSCLC patients with the mutation status of EGFR in their cancerous tissues. Both EGFR mutations and ALK rearrangements were identified in 19 (14.39\%) and 1 (1.96\%) patients, respectively. We found EGFR mutations in codon 861,719 and 858 with the ratios of $10.52 \%(2 / 19), 10.52 \%(2 / 19)$ and $31.58 \%(6 / 19)$, respectively, and deletion of exon 19 in $47.37 \%$ (9/19) of the patients. We found the frequency of EGFR mutations to be significantly higher in female patients and nonsmokers ( $p=0.043, p=0.027$, respectively). Consequently, we found EGFR mutations to be more frequent in female patients and nonsmokers. Future studies on larger patient groups would provide more accurate data to exhibit the relationship between EGFR mutations and ALK rearrangements and the clinicopathological status.
\end{abstract}

Keywords: Lung cancer, Non-small cell lung cancer, EGFR mutations, ALK rearrangement

\section{Background}

Lung cancer is the most common cause of cancer-related deaths in males and females worldwide (Jemal et al. 2010). Non-small cell lung cancer (NSCLC) accounts for $80-85 \%$ of all lung cancers. Most of the patients have advanced stages or metastatic disease (D'Addario et al. 2010; Crinò et al. 2010). A recent improvement in comprehending the molecular basis of the disease, especially NSCLC, has led to improvements in treatment (Mok et al. 2009). In recent years, because of the development of biomarker-driven personalized therapy, the treatment approach for many cancers including the NSCLC has changed (Vagulienè et al. 2012). Various

\footnotetext{
*Correspondence: tahyakut@gmail.com

1 Department of Medical Genetics, Faculty of Medicine, Uludag University, 16059 Görükle, Bursa, Turkey

Full list of author information is available at the end of the article
}

phase 3 trials have demonstrated the clinical efficacy of EGFR tyrosine kinase inhibitors (gefitinib and erlotinib) as first-line therapies compared with chemotherapy in advanced stage NSCLC patients with harboring activating EGFR mutations. Some clinical practice guidelines suggest testing EGFR mutation status before initiating the first-line treatment to patients with advanced stage NSCLC (Shi et al. 2014). The EGFR gene is localized on the short arm of chromosome 7 and encodes a 170$\mathrm{kDa}$ type I transmembrane growth factor receptor. The EGFR receptor belongs to the HER/erbB family of tyrosine kinase. This receptor has an extracellular cysteinerich ligand-binding domain and an intracellular domain which has intrinsic tyrosine kinase activity. Intracellular signaling is mediated mainly by the RAS-RAF-MEKMAPK pathway, PI3K-PTEN-AKT pathway and the signal transducer and activator of transcription (STAT) pathways (De Luca et al. 2008). These EGFR signaling 
pathways are important for tumor cell growth, local invasion, angiogenesis, protein translation, autophagy and cell metabolism (Jimeno and Hidalgo 2006). Echinoderm microtubule-associated protein-like 4 and the anaplastic lymphoma kinase (EML4-ALK) fusion genes were identified in a subset of NSCLCs in 2007 (Soda et al. 2007). This fusion occurs due to chromosomal inversion or the translocation of chromosome $2 \mathrm{p}$ and results in the formation of EML4-ALK fusion gene.

The EML4-ALK translocation results in constitutive ALK kinase activity and represents the oncogenic addiction pathway in NSCLC (Soda et al. 2007, 2008). The ALK rearrangements that are found in up to $5 \%$ of patients with NSCLC are related to younger age, no history of smoking and distinct clinicopathological features such as adenocarcinoma histology (Shaw et al. 2009; Solomon et al. 2009; Tiseo et al. 2011; Wong et al. 2009). Crizotinib, a targeted ALK tyrosine kinase inhibitor (TKI), is a promising agent in treating ALK-positive NSCLC patients and provides survival benefit (Kwak et al. 2010). It was approved by the US Food and Drug Administration (FDA) for treating advanced stage ALK-positive lung cancer.

The aim of the study was to examine the prevalence of EGFR-activating mutations and ALK rearrangements among patients with NSCLC and to evaluate the associations between EGFR mutations and clinicopathological characteristics.

\section{Methods}

One hundred and thirty two patients applying to Uludağ University Faculty of Medicine, Medical Genetics Department for EGFR mutation analysis and 51 patients applying for ALK translocation analysis with histopathologically proven NSCLC were enrolled in this retrospective study. The demographic (age, gender) and clinicopathological characteristics of the patients (smoking status, histological type and metastatic status) were compared with the results of molecular analysis. Approval for the study was granted by the local ethics committee.

\section{EGFR mutation analysis using pyrosequencing}

Formalin-fixed paraffin embedded tissue samples were obtained by tumor biopsy. The slides were examined by pathologists to confirm that they contain more than $50 \%$ of tumoral tissue, and they are appropriate for DNA extraction. The QIAamp ${ }^{\circledR}$ DNA FFPE tissue kits were used to extract the human DNA from formalinfixed paraffin-embedded tissue specimens $\left(\right.$ QIAGEN $^{\circledR}$ kit, Germany). Single-stranded DNA was prepared, and the corresponding sequencing primers were annealed to the DNA. Therascreen EGFR Pyro Kit can detect and measure the mutations in human EGFR gene 719, 768, 790 , and 858-861 codons quantitatively and also detect the deletions and complex mutations in exon 19. The kit includes 4 PCR assays: one for detecting the mutations in codon 719 (exon 18), one for 768 and 790 (exon 20), one for codons 858-861 (exon 21) and one for the deletions in exon 19. Four regions were amplified separately and sequenced through the defined region. After using primers targeting 18, 19, 20 and 21, amplicons were immobilized on Streptavidin Sepharose High Performance beads. The samples were analyzed in a PyroMark Q24 system using Assay setup files and a run setup file. The unmethylated control DNA was included in the study as a positive control for the PCR and sequence analyses. Additionally, negative controls (without template DNA) were included per each PCR set up for at least one assay.

\section{Fluorescent in situ hybridization (FISH) for EML4-ALK fusion}

Formalin-fixed, paraffin-embedded tissue sections were localized on slides. The DNA was denatured to a singlestranded form and was hybridized with DNA probes. Following the hybridization, the undyed probes were removed by a washing series, and the nuclei were counter-stained with DAPI (4,6 diamidino-2-phenylindole) (a DNA-specific stain that fluoresces blue). The hybridization of ALK probe (Vysis LSI ALK Dual Color, breakapart rearrangement probe; Abbott Molecular, Abbott Park, IL) was examined using a fluorescence microscope equipped with appropriate excitation and emission filters, allowing the visualization of the orange and green fluorescent signals. If 2p23 ALK region is hybridized with Vysis ALK Break Apart FISH Probes, it appears as two adjacent or fused (overlapping) orange/green (yellow) signals in a natural position. However, if a chromosome rearrangement at the 2 p23 ALK breakpoint region has occurred, one orange and one green signal separated by at least two signal diameters will be visualized. Alternatively, a single orange signal (deletion of green signal) in addition to a fused or broken apart signal may be seen. If more than 100 tumor cells are counted, if $>15 \%$ of tumor cells showed a split red and green and/or single red pattern, then the occurrence of an ALK gene rearrangement is considered; otherwise, the specimen is classified as $A L K$ FISH negative. The ALK positivity pattern (split, single red or both) was recorded.

\section{Statistical analysis}

The age variable was presented with median value (minimum-maximum), and the other categorical variables of the study were presented in numbers and percentages. The Pearson's Chi square and Fisher's exact Chi square tests were used for the comparisons of categorical 
variables between mutation groups. Analyses were performed with SPSS 22.0 (Chicago, IL) program, and $\mathrm{p}<0.05$ was considered statistically significant.

\section{Results}

The median age of 132 patients with NSCLC diagnosis was 60 (31-83) years. The demographic and clinicopathological characteristics of the patients are given in Table 1. EGFR mutation and ALK rearrangements were detected in $14.39 \%(19 / 132)$ and $1.96 \%(1 / 51)$ of the patients, respectively. We found EGFR mutations in codon 861,719 , and 858 in the following ratios: $10.52 \%$ (2/19), $10.52 \%(2 / 19)$ and $31.58 \%(6 / 19)$ and detected exon 19 deletion in $47.37 \%$ of the patients (9/19). Among all mutations, we found exon 19 deletions delE746-A750 and delL747-p753, InsS with ratios of $42.11 \%(8 / 19)$ and $5.26 \%(1 / 19)$, respectively. In one patient with codon 719 mutation, we also detected a mutation at codon 790. The comparison of clinicopathological characteristics of EGFR mutation carriers and wild type patients is presented in Table 1 . The patients were classified as adenocarcinoma and the others (squamous, giant cell, adenosquamous) in terms of histological type.

EGFR mutation rates were higher in females than males $(\mathrm{p}=0.043)$ and higher in non-smokers than smokers $(\mathrm{p}=0.027)$. We did not find additional significant associations between EGFR mutation and patients' clinicopathological characteristics (Table 1). Clinicopathological characteristics of a 54 year old female patient who had ALK rearrangements and EGFR wild type was smoker, adenocarcinoma histology and presence of metastasis.

\section{Discussion}

The molecular basis of lung cancer is complex and heterogeneous. The molecular changes in multiple levels (genetic, epigenetic, protein expression) and the improvements in the comprehension of the functional expressiveness of these changes have potential effects for the diagnosis, prognostication and treatment of lung cancer. EGFR mutations are related to the pathogenesis of many types of cancers including NSCLC (Cooper et al. 2013). Activating mutations of the EGFR gene were reported in $10-15 \%$ of unselected Western patients (Yip et al. 2013; Shigematsu et al. 2005; Eberhard et al. 2008; Russell et al. 2013) and 30-40 \% of Asian populations (Kosaka et al. 2004; Tokumo et al. 2005; Yoshida et al. 2007). EGFR mutations in NSCLC are seen in the first 4 exons of intracellular tyrosine kinase domain. They are most commonly frame deletions of exon $19(\sim 45 \%)$ and have over 20 variants, and the most common of which is delE746-A750. The next most common mutations are missense mutations, particularly L858R in exon 21, a single nucleotide point mutation leading to a single amino acid change from leucine to arginine at codon 858 ( $40 \%)$. However, Yip et al. reported that $14 \%$ of the EGFR mutations of patients with early stage lung cancers comprised

Table 1 The demographic and clinicopathological characteristics of the patients and the comparison of clinicopathological characteristics of EGFR mutation carriers and wild type patients

\begin{tabular}{|c|c|c|c|c|}
\hline Characteristics & All patients $(n=132)$ & $\begin{array}{l}\text { Patients with EGFR } \\
\text { mutation }(n=19)\end{array}$ & $\begin{array}{l}\text { Patients with EGFR } \\
\text { wild } \\
\text { type }(n=113)\end{array}$ & $p$ value \\
\hline Age & & & & 0.556 \\
\hline$<65$ & 91 (68.9\%) & $12(13.2 \%)$ & 79 (86.8 \%) & \\
\hline$\geq 65$ & 41 (31.1\%) & $7(17.1 \%)$ & 34 (82.9\%) & \\
\hline Gender & & & & 0.043 \\
\hline Male & $98(74.2 \%)$ & 10 (10.2\%) & 88 (89.8 \%) & \\
\hline Female & $34(25.8 \%)$ & $9(26.5 \%)$ & $25(73.5 \%)$ & \\
\hline Smoking status & & & & $0.027^{*}$ \\
\hline Never & $60(45.5 \%)$ & $13(21.7 \%)$ & 47 (78.3 \%) & \\
\hline Ever & $56(42.4 \%)$ & 4 (7.1\%) & 52 (92.9\%) & \\
\hline Unknown & $16(12.1 \%)$ & $2(12.5 \%)$ & $14(87.5 \%)$ & \\
\hline Histology & & & & 0.546 \\
\hline Adenocarcinoma & $127(96.2 \%)$ & $18(14.2 \%)$ & 109 (85.8 \%) & \\
\hline Others & $5(3.8 \%)$ & 1 (20 \%) & 4 (80 \%) & \\
\hline Metastasis status & & & & 0.780 \\
\hline Present & 98 (74.2 \%) & $15(15.3 \%)$ & 83 (84.7 \%) & \\
\hline Absent & 34 (25.8 \%) & $4(11.8 \%)$ & 30 (88.2 \%) & \\
\hline
\end{tabular}

EGFR epidermal growth factor receptor

* $\mathrm{p}$ value were derived from a comparison between never and ever smoking status 
activating mutations of exon 18 and that L858R mutations accounted for only $29 \%$ of EGFR mutations in an Australian population (Yip et al. 2013). Additionally, there are less common types of mutations including the frame duplications and insertions in exon $20(\sim 5-10 \%)$, most of which are related to EGFR-TKI resistance (Tam et al. 2006; Yamamoto et al. 2009). Doğan et al. reported that all of the EGFR mutations they detected in $7.4 \%$ of 42 patients with advanced stage NSCLC were exon 19 deletions (Dogan et al. 2014). Shigematsu and Gazdar (2005), one of two major series (Shigematsu and Gazdar 2005; Murray et al. 2008) on epidemiology of EGFR mutations stated that all the reported mutations were somatic mutations at exon 18-21 of EGFR gene encoding a part of intracellular TK domain. Three different mutation types related to EGFRTKIs sensitivity were defined: (1) in-frame deletions at exon 19 which are the most common mutations accounting for $46 \%$ of EGFR mutations, (2) missense mutations at exon 18,20 or 21 (primarily the single-nucleotide substitutions, L858R at exon 21) that are the second most common mutations accounting for $41 \%$ of EGFR mutations and (3) in-frame duplications/insertions at exon 20 that constitute $5 \%$ of all EGFR mutations. It was found that EGFR mutations are associated with EGFR-TKIs sensitivity as well as East Asian ethnicity, female gender, no history of smoking and adenocarcinoma histology.

Murray et al. (2008) screened the data of 12,244 patients and noted 3381 EGFR mutations. Exon 19 mutations were the most common (50\%) followed by exon 21 (40\%), 20 (6\%), and 18 mutations (4\%). Whereas L858R and delE746-A750 constituted 32.8 and $24.3 \%$, respectively, $50 \%$ of the mutations were deletions of exon 19 or deletion-insertions. There was a significant relationship between TKI response and presence of mutation, and although exon 19 mutations have the best response rates $(70 \%)$, exons 21,18 and 20 have a response rate of approximately $20 \%$ or slightly more (Shigematsu and Gazdar 2005; Murray et al. 2008). Ünal et al. found EGFR mutations in $42.6 \%$ of 48 patients with NSCLC in their study in Western Turkey in which 9 of the mutations were at exon 20; 7 were at exon 19 and 2 were at exon 21 (Unal et al. 2013). In the present study, we detected EGFR mutations in $14.39 \%$ (19/132) of NSCLC patients, and the mutations were in codons 861,719 and 858 with the following rates: $10.52 \%(2 / 19), 10.52 \%(2 / 19)$ and $31.58 \%(6 / 19)$, respectively, and deletion of exon 19 was seen in a ratio of $47.37 \%(9 / 19)$. delE746-A750 accounted for $42.11 \%$ of all mutations, and it was the most common mutation. Our results were consistent with the literature.

The data from the literature indicate that the mutations are more frequent in females compared with males (42 vs. $14 \%$ ), in non-smokers compared with smokers (51 vs. $10 \%)$ and in patients with tumor histology of adenocarcinoma compared with other types (40 vs. 3 \%) (Jimeno and Hidalgo 2006; Paez et al. 2004; Lynch et al. 2004; Pao et al. 2004; Shigematsu and Gazdar 2006; Mitsudomi et al. 2006; Jänne et al. 2004; Sakurada et al. 2006). Additionally, Vaguliene et al. found that EGFR mutations were significantly more frequent in females and nonsmokers in a study of 103 patients with NSCLC (Vaguliene et al. 2012). Ünal et al. found that EGFR mutations were significantly more frequent in non-smoking NSCLC patients in Western Turkey (Unal et al. 2013). In contrast to majority of published data, Skov et al. (2015) and Hsiao et al. (2014) found no difference in mutation rate among men and women. In our study, we found that EGFR mutations were more common in females and non-smokers.

In former studies, ALK rearrangement frequency was reported to be 3-13\% using FISH technique in NSCLC patients (Shaw et al. 2009; Inamura et al. 2008; Lin et al. 2009). In those studies, it was stated that ALK rearrangements were more common in nonsmoking patients, younger patients and adenocarcinoma histology and that it rarely coincided with the presence of an EGFR mutation (Shaw et al. 2009; Wong et al. 2009; Takahashi et al. 2010). Wang et al. detected ALK rearrangements in $9.6 \%$ (32/332) of 332 patients with primary lung adenocarcinoma (Wang et al. 2014). In the present study, we found ALK rearrangement in $1.96 \%$ (1/51) of our patients; however, we could not establish an association with clinicopathological parameters due to a limited number of patients with ALK rearrangements.

A few weaknesses of the study should be mentioned. First, this is a single center study. Second, our study was performed on a relatively small population. Finally, although the cohort is complete and genetically homogenous, the mutation rate is dependent on the prevalence of smoking.

\section{Conclusions}

We detected EGFR mutation and ALK rearrangements at proportions of 14.39 and $1.96 \%$, respectively. We found that EGFR mutations were significantly more common in females and nonsmokers. The distinctness in prevalence reported in various studies may be related to differences in patient populations and may also stem from the diversity in sensitivity of the techniques to analyze mutations. Further studies in larger patient groups would provide more accurate information to exhibit the association between clinicopathological characteristics and EGFR mutations and ALK rearrangements.

\section{Authors' contributions}

SOS and OG have made substantial contributions to conception and design, analysis, interpretation of data and drafted the manuscript. AD and EK carried out the clinical contact and guidance. TY and TG participated in the revising 
the article critically for important intellectual content. SOS and OG participated in the design of the study and performed the statistical analysis. MT, SS, AT participated in EGFR mutation analysis and ALK translocation analysis. All authors read and approved the final manuscript.

\section{Author details}

1 Department of Medical Genetics, Faculty of Medicine, Uludag University, 16059 Görükle, Bursa, Turkey. ${ }^{2}$ Department of Medical Genetics, Sevket YIImaz Education and Research Hospital, 16310 Yıldırım, Bursa, Turkey. ${ }^{3}$ Division of Medical Oncology, Department of Internal Medicine, Faculty of Medicine, Uludag University, 16059 Görükle, Bursa, Turkey.

\section{Acknowledgements}

Professional English proofreading was provided by the American Journal of Experts.

\section{Competing interests}

The authors declare that they have no competing interests.

Received: 28 October 2015 Accepted: 12 April 2016

Published online: 19 April 2016

\section{References}

Cooper WA, Lam DC, O'Toole SA, Minna JD (2013) Molecular biology of lung cancer. J Thorac Dis 5:479-490

Crinò L, Weder W, Van Meerbeeck J, Felip E, ESMO Guidelines Working Group (2010) Early stage and locally advanced (non-metastatic) non-small-cell lung cancer: ESMO Clinical Practice Guidelines for diagnosis, treatment and follow-up. Ann Oncol 21:103-115

D’Addario G, Früh M, Reck M, Baumann P, Klepetko W, Felip E, ESMO Guidelines Working Group (2010) Metastatic non-small-cell lung cancer: ESMO Clinical Practice Guidelines for diagnosis, treatment and follow-up. Ann Oncol 21:116-119

De Luca A, Carotenuto A, Rachiglio A, Gallo M, Maiello MR, Aldinucci D, Pinto A, Normanno N (2008) The role of the EGFR signaling in tumor microenvironment. J Cell Physiol 214:559-567

Dogan M, Demirkazik A, Tukun A, Sak SD, Ceyhan K, Yalcin B, Akbulut H, Icli F (2014) The relationship between common EGFR, BRAF, KRAS mutations and prognosis in advanced stage non-small cell lung cancer with response to the treatment in Turkey. UHOD 24:001-010

Eberhard DA, Giaccone G, Johnson BE (2008) Biomarkers of response to epidermal growth factor receptor inhibitors in non-small-cell lung cancer working group: standardization for use in the clinical trial setting. J Clin Oncol 26:983-994

Hsiao SH, Lin SE, Chou YT, Wang JL, Chung CL, Yu MC, Fang CL, Lee HL, Chiang LL, Liu HE, Wu CW (2014) Histological subtype and smoking status, but not gender, are associated with epidermal growth factor receptor mutations in non-small-cell lung cancer. Mol Clin Oncol 2:252-258

Inamura K, Takeuchi K, Togashi Y, Nomura K, Ninomiya H, Okui M, Satoh Y, Okumura S, Nakagawa K, Soda M, Choi YL, Niki T, Mano H, Ishikawa Y (2008) EML4-ALK fusion is linked to histological characteristics in a subset of lung cancers. J Thorac Oncol 3:13-17

Jänne PA, Gurubhagavatula S, Yeap BY, Lucca J, Ostler P, Skarin AT, Fidias P, Lynch TJ, Johnson BE (2004) Outcomes of patients with advanced non-small cell lung cancer treated with gefitinib (ZD1839, "Iressa") on an expanded access study. Lung Cancer 44:221-230

Jemal A, Siegel R, Xu J, Ward E (2010) Cancer statistics. CA Cancer J Clin 60:277-300

Jimeno A, Hidalgo M (2006) Pharmacogenomics of epidermal growth factor receptor (EGFR) tyrosine kinase inhibitors. Biochim Biophys Acta 1766:217-229

Kosaka T, Yatabe Y, Endoh H, Kuwano H, Takahashi T, Mitsudomi T (2004) Mutations of the epidermal growth factor receptor gene in lung cancer: biological and clinical implications. Cancer Res 64:8919-8923

Kwak EL, Bang YJ, Camidge DR, Shaw AT, Solomon B, Maki RG, Ou SH, Dezube BJ, Jänne PA, Costa DB, Varella-Garcia M, Kim WH, Lynch TJ, Fidias P, Stubbs H, Engelman JA, Sequist LV, Tan W, Gandhi L, Mino-Kenudson M, Wei GC, Shreeve SM, Ratain MJ, Settleman J, Christensen JG, Haber DA, Wilner K,
Salgia R, Shapiro Gl, Clark JW et al (2010) Anaplastic lymphoma kinase inhibition in non-small-cell lung cancer. N Engl J Med 363:1693-1703

Lin E, Li L, Guan Y, Soriano R, Rivers CS, Mohan S, Pandita A, Tang J, Modrusan Z (2009) Exon array profiling detects EML4-ALK fusion in breast, colorectal, and non-small cell lung cancers. Mol Cancer Res 7:1466-1476

Lynch TJ, Bell DW, Sordella R, Gurubhagavatula S, Okimoto RA, Brannigan BW, Harris PL, Haserlat SM, Supko JG, Haluska FG, Louis DN, Christiani DC, Settleman J, Haber DA (2004) Activating mutations in the epidermal growth factor receptor underlying responsiveness of non-small-cell lung cancer to gefitinib. N Engl J Med 350:2129-2139

Mitsudomi T, Kosaka T, Yatabe Y (2006) Biological and clinical implications of EGFR mutations in lung cancer. Int J Clin Oncol 11:190-198

Mok TS, Wu YL, Thongprasert S, Yang CH, Chu DT, Saijo N, Sunpaweravong P, Han B, Margono B, Ichinose Y, Nishiwaki Y, Ohe Y, Yang JJ, Chewaskulyong B, Jiang H, Duffield EL, Watkins CL, Armour AA, Fukuoka M (2009) Gefitinib or carboplatin-paclitaxel in pulmonary adenocarcinoma. N Engl J Med 361:947-957

Murray S, Dahabreh IJ, Linardou H, Manoloukos M, Bafaloukos D, Kosmidis P (2008) Somatic mutations of the tyrosine kinase domain of epidermal growth factor receptor and tyrosine kinase inhibitor response to TKls in nonsmall cell lung cancer: an analytical database. J Thorac Oncol 3:832-839

Paez JG, Jänne PA, Lee JC, Tracy S, Greulich H, Gabriel S, Herman P, Kaye FJ, Lindeman N, Boggon TJ, Naoki K, Sasaki H, Fujii Y, Eck MJ, Sellers WR, Johnson BE, Meyerson M (2004) EGFR mutations in lung cancer: correlation with clinical response to gefitinib therapy. Science 304:1497-1500

Pao W, Miller V, Zakowski M, Doherty J, Politi K, Sarkaria I, Singh B, Heelan R, Rusch V, Fulton L, Mardis E, Kupfer D, Wilson R, Kris M, Varmus H (2004) EGF receptor gene mutations are common in lung cancers from "never smokers" and are associated with sensitivity of tumors to gefitinib and erlotinib. Proc Natl Acad Sci USA 101:13306-13311

Russell PA, Barnett SA, Walkiewicz M, Wainer Z, Conron M, Wright GM, Gooi J, Knight S, Wynne R, Liew D, John T (2013) Correlation of mutation status and survival with predominant histologic subtype according to the new IASLC/ATS/ERS lung adenocarcinoma classification in stage III (N2) patients. J Thorac Oncol 8:461-468

Sakurada A, Shepherd FA, Tsao MS (2006) Epidermal growth factor receptor tyrosine kinase inhibitors in lung cancer: impact of primary or secondary mutations. Clin Lung Cancer 7:138-144

Shaw AT, Yeap BY, Mino-Kenudson M, Digumarthy SR, Costa DB, Heist RS, Solomon B, Stubbs H, Admane S, McDermott U, Settleman J, Kobayashi S, Mark EJ, Rodig SJ, Chirieac LR, Kwak EL, Lynch TJ, lafrate AJ (2009) Clinical features and outcome of patients with non-small-cell lung cancer who harbor EML4-ALK. J Clin Oncol 27:4247-4253

Shi Y, Au JS, Thongprasert S, Srinivasan S, Tsai CM, Khoa MT, Heeroma K, Itoh Y, Cornelio G, Yang PC (2014) A prospective, molecular epidemiology study of EGFR mutations in Asian patients with advanced non-small-cell lung cancer of adenocarcinoma histology (PIONEER). J Thorac Oncol 9:154-162

Shigematsu H, Gazdar A (2005) The epidemiology of EGFR mutations. Signal 6:4-8

Shigematsu H, Gazdar AF (2006) Somatic mutations of epidermal growth factor receptor signaling pathway in lung cancer. Int J Cancer 118:257-262

Shigematsu H, Lin L, Takahashi T, Nomura M, Suzuki M, Wistuba II, Fong KM, Lee H, Toyooka S, Shimizu N, Fujisawa T, Feng Z, Roth JA, Herz J, Minna JD, Gazdar AF (2005) Clinical and biological features associated with epidermal growth factor receptor gene mutations in lung cancers. J Natl Cancer Inst 97:339-346

Skov BG, Høgdall E, Clementsen P, Krasnik M, Larsen KR, Sørensen JB, Skov T, Mellemgaard A (2015) The prevalence of EGFR mutations in nonsmall cell lung cancer in an unselected Caucasian population. APMIS 123:108-115

Soda M, Choi YL, Enomoto M, Takada S, Yamashita Y, Ishikawa S, Fujiwara S, Watanabe H, Kurashina K, Hatanaka H, Bando M, Ohno S, Ishikawa Y, Aburatani H, Niki T, Sohara Y, Sugiyama Y, Mano H (2007) Identification of the transforming EML4-ALK fusion gene in non-small-cell lung cancer. Nature 448:561-566

Soda M, Takada S, Takeuchi K, Choi YL, Enomoto M, Ueno T, Haruta H, Hamada T, Yamashita Y, Ishikawa Y, Sugiyama Y, Mano H (2008) A mouse model for EML4-ALK-positive lung cancer. Proc Natl Acad Sci USA 105:19893-19897

Solomon B, Varella-Garcia M, Camidge DR (2009) ALK gene rearrangements: a new therapeutic target in a molecularly defined subset of non-small cell lung cancer. J Thorac Oncol 4:1450-1454 
Takahashi T, Sonobe M, Kobayashi M, Yoshizawa A, Menju T, Nakayama E, Mino N, Iwakiri S, Sato K, Miyahara R, Okubo K, Manabe T, Date H (2010) Clinicopathologic features of non-small-cell lung cancer with EML4-ALK fusion gene. Ann Surg Oncol 17:889-897

Tam IY, Chung LP, Suen WS, Wang E, Wong MC, Ho KK, Lam WK, Chiu SW, Girard L, Minna JD, Gazdar AF, Wong MP (2006) Distinct epidermal growth factor receptor and KRAS mutation patterns in non-small cell lung cancer patients with different tobacco exposure and clinicopathologic features. Clin Cancer Res 12:1647-1653

Tiseo M, Gelsomino F, Bartolotti M, Bordi P, Bersanelli M, Rossi G, Ardizzoni A (2011) Anaplastic lymphoma kinase as a new target for the treatment of non-small-cell lung cancer. Expert Rev Anticancer Ther 11:1677-1687

Tokumo M, Toyooka S, Kiura K, Shigematsu H, Tomii K, Aoe M, Ichimura K, Tsuda T, Yano M, Tsukuda K, Tabata M, Ueoka H, Tanimoto M, Date H, Gazdar AF, Shimizu N (2005) The relationship between epidermal growth factor receptor mutations and clinicopathologic features in non-small cell lung cancers. Clin Cancer Res 11:1167-1173

Unal OU, Oztop I, Calibasi G, Baskin Y, Koca D, Demir N, Akman T, Ellidokuz H, Yilmaz AU (2013) Relationship between epidermal growth factor receptor gene mutations and clinicopathological features in patients with non-small cell lung cancer in western Turkey. Asian Pac J Cancer Prev 14:3705-3709
Vagulienè N, Žemaitis M, Šarauskas V, Vitkauskienè A, Miliauskas S (2012) The role of mutation status of the epidermal growth factor receptor gene in advanced non-small cell lung cancer. Medicina (Kaunas) 48:175-181

Wang J, Dong Y, Cai Y, Zhou L, Wu S, Liu G, Su D, Li X, Qin N, Nong J, Jia H, Zhang Q, Mu J, Zeng X, Zhang H, Zhang S, Zhang Z (2014) Clinicopathologic characteristics of ALK rearrangements in primary lung adenocarcinoma with identified EGFR and KRAS status. J Cancer Res Clin Oncol 140:453-460

Wong DW, Leung EL, So KK, Tam IY, Sihoe AD, Cheng LC, Ho KK, Au JS, Chung LP, Pik Wong M, University of Hong Kong Lung Cancer Study Group (2009) The EML4-ALK fusion gene is involved in various histologic types of lung cancers from nonsmokers with wild-type EGFR and KRAS. Cancer 115:1723-1733

Yamamoto H, Toyooka S, Mitsudomi T (2009) Impact of EGFR mutation analysis in non-small cell lung cancer. Lung Cancer 63:315-321

Yip PY, Yu B, Cooper WA, Selinger Cl, Ng CC, Kennedy CW, Kohonen-Corish MR, McCaughan BC, Trent RJ, Boyer MJ, Kench JG, Horvath LG, O'Toole SA (2013) Patterns of DNA mutations and ALK rearrangement in resected node negative lung adenocarcinoma. J Thorac Oncol 8:408-414

Yoshida K, Yatabe Y, Park JY, Shimizu J, Horio Y, Matsuo K, Kosaka T, Mitsudomi T, Hida T (2007) Prospective validation for prediction of gefitinib sensitivity by epidermal growth factor receptor gene mutation in patients with non-small cell lung cancer. J Thorac Oncol 2:22-28

\section{Submit your manuscript to a SpringerOpen ${ }^{\odot}$ journal and benefit from:}

- Convenient online submission

- Rigorous peer review

- Immediate publication on acceptance

- Open access: articles freely available online

- High visibility within the field

- Retaining the copyright to your article

Submit your next manuscript at springeropen.com 